2015

Factors affecting university image

formation among prospective higher

education students: the case of

international branch campuses

Wilkins, S

http://hdl.handle.net/10026.1/3937

10.1080/03075079.2014.881347

STUDIES IN HIGHER EDUCATION

All content in PEARL is protected by copyright law. Author manuscripts are made available in accordance with publisher policies. Please cite only the published version using the details provided on the item record or document. In the absence of an open licence (e.g. Creative Commons), permissions for further reuse of content should be sought from the publisher or author. 
Wilkins, S. and Huisman, J. (2014). Factors affecting university image formation among prospective higher education students: the case of international branch campuses. Studies in Higher Education, published online before print, $8^{\text {th }}$ April 2014. http://dx.doi.org/10.1080/03075079.2014.881347.

\title{
Factors affecting university image formation among prospective higher education students: the case of international branch campuses
}

\author{
Stephen Wilkins \\ Plymouth University, Plymouth, UK \\ Jeroen Huisman \\ University of Ghent, Ghent, Belgium
}

Previous research has found that the images of universities formed by prospective students greatly influence their choices. With the advent of international branch campuses in several higher education hubs worldwide, many international students now attempt to construct images of these institutions when deciding where to study. The aim of this research is to identify the sources of information and other influences that impact upon the images of international branch campuses formed by prospective undergraduate students. The study involved 407 students studying at nine international schools in the United Arab Emirates (UAE). It was found that recommendations and feedback resulting from personal relationships was by far the most influential factor shaping the images of institutions constructed by students. It was also discovered that elite institutions can benefit from positive home campus images based on heritage and prestige, which positively influence the images constructed of the international branch campuses operated by these institutions. The implications of the findings for higher education institutions are discussed.

Keywords: student choice, information sources, organisational image, international branch campuses, higher education marketing

\section{Introduction}

The term 'image' is generally used by researchers in the marketing domain to refer to the actual perceptions of an organisation held by external stakeholders (Brown et al. 2006). Stakeholders are those who may directly or indirectly benefit or lose from the organisation's activities, hence why they have an interest (stake) in the organisation's performance (Benneworth and Jongbloed 2010). Karaosmanoglu and Melewar $(2006,198)$ define corporate image as, 'the set of meanings by which an object is known and through which people describe, remember and relate to it ...it is the net result of the interaction of a person's beliefs, ideas, feelings and impressions about an organisation at a particular moment in time.'

While numerous studies have examined aspects of corporate image with respect to business organisations, few have examined university image (Arpan, Raney, and Zivnuska 2003). As universities have become more exposed to competitive market forces, marketing has become more important in contributing to the creation of favourable institutional images that will help attract students, staff and resources. This becomes even more important in a context in which the number of students studying outside their home country increases significantly; the OECD (2011) reported that 3.7 million students were studying abroad in 2009. We realise that a focus on markets, brands, images and students as consumers may suggest we uncritically embrace a neo-liberal perspective on higher education. Our intention is, however, to use insights from a well-established strand of marketing literature to analyse a phenomenon in higher education. Our neutral definition above of 
Wilkins, S. and Huisman, J. (2014). Factors affecting university image formation among prospective higher education students: the case of international branch campuses. Studies in Higher Education, published online before print, $8^{\text {th }}$ April 2014. http://dx.doi.org/10.1080/03075079.2014.881347.

'image' illustrates our stance and our use of the concept of the student as consumer is merely metaphorical, and acknowledges that students can perform different roles in higher education (see McCulloch 2009; Tight 2013).

To our knowledge, no study has yet considered the images of international branch campuses. International branch campuses are owned by higher education institutions and are located outside the countries in which these institutions are based. International branch campuses might be considered similar in nature to the overseas business units of multinational business corporations. The majority of international branch campuses are run as for-profit ventures, which has led higher education institutions to develop marketing strategies similar to those implemented by business organisations. During the last decade, the number of international branch campuses established worldwide has mushroomed. In January 2012, there were at least 200 international branch campuses operating worldwide (Lawton and Katsomitros 2012).

Since the turn of the century, countries such as Malaysia, Qatar, Singapore and the United Arab Emirates (UAE) have established themselves as regional higher education hubs. International branch campuses have provided much, if not most, of the new higher education capacity at these hubs. They generally cater for both domestic (host country nationals) and international students (expatriates already residing in the host country and those entering the host country on a student visa mainly for educational purposes). Students, particularly those living in or close to a higher education hub, now often compare international branch campuses with home campuses in the traditional destinations for international students - such as Australia, the United Kingdom (UK) and United States (US) - when deciding where to study. Wilkins, Balakrishnan, and Huisman (2011) found that students can be attracted to international branch campuses for a variety of convenience and country-specific reasons.

It is possible that students find it difficult to form strong and cohesive images of international branch campuses since most of these institutions are too new to have developed reputations and it is possible that overall images are influenced by a complex mix of factors relating to both the branch and home campuses. As organisations expand to new geographic locations, the perceptions of stakeholders - including potential customers locally - may vary greatly (Spittal and Abratt 2009). When deciding on the institution at which to study, students rely on diverse sources of information to form images of different universities, and they may also be influenced by a range of people including friends, family, teachers and higher education advisers. Organisational image is particularly important in services - including higher education - because users have to evaluate alternatives without any direct experience of the product (Moogan, Baron, and Harris 1999). Baldwin and James (2000) found that for most higher education applicants, assessments of institutional reputations are based on flimsy hearsay evidence rather than on specific and accurate information provided by institutions or regulatory bodies, which suggests that images do matter.

Given the arguably increasing importance of images and the rise of the international branch campus, the purpose of this research is to explore how international students form images of international branch campuses. We focus on prospective undergraduate students, using a representative sample of high school students in the UAE. We examine the extent to which different sources of information and other influences affect the images formed by students with the aim of identifying the sources of information and influence that contribute most to students' ability to form (in their opinion) strong, clear and accurate images of international branch campuses.

In the following section, we consider the role of information searching in the decision-making process of prospective higher education students. Then, we present our method and the results of our survey. The next section provides a discussion that summarises and analyses our main findings, and it compares our findings with the results of other studies. This is followed by a consideration of the implications of our findings for higher education institutions, particularly for those that own and operate international branch campuses, and it provides implicit recommendations for institutions. Finally, the conclusion addresses the key contributions of the paper in relation to the literature on student decision-making. 
Wilkins, S. and Huisman, J. (2014). Factors affecting university image formation among prospective higher education students: the case of international branch campuses. Studies in Higher Education, published online before print, $8^{\text {th }}$ April 2014. http://dx.doi.org/10.1080/03075079.2014.881347.

\section{The decision-making process of international students}

The decision-making process of international students is a complex task that is subject to multiple influences. Consumer decision-making is commonly conceptualised as a five-stage process that involves need recognition; information search; evaluation of alternatives; purchase/consumption; and finally, post-consumption evaluation (Maringe and Carter 2007). This research relates to the second and third stages of this process, as it is concerned with the information that students gather to help choose a university and the impact of different sources of information (e.g. recommendations from friends and family) on institutional image formation and evaluation.

Obviously, the international student choice literature builds on the general student choice literature (for seminal work and models, see e.g. Chapman 1981; Hossler, Schmit, and Vesper 1999; Eccles and Wigfield 2002, and for recent research e.g. Dunnett et al. 2012; Mangan, Hughes, and Slack 2010). But this literature - almost by default, given its focus on domestic students' choices may have underemphasised the potential role of images and cultural differences in a globalised world, and may have had a different (rather regional) perception of the impact of geographical distance. Moreover, much of the student choice literature has focused on background characteristics of students (particularly social class, e.g. Ball et al. 2002) or on pupils' preferences for particular subjects (e.g. Holmegaard et al. 2012; Mikkonen et al. 2009) or on the role of the secondary school (e.g. Smyth and Banks 2012). While this literature reveals much about student motivations, expectations and interests (i.e. the students' identity-formation), it is largely silent on the role of the identity (or image) of the higher education institutions. Two studies that did incorporate higher education institutions' identity or image are discussed below.

Building on various models, Vrontis, Thrassou, and Melanthiou (2007) developed a generic model of student choice for developed countries. The model consists of a core, which represents the basic five stages of student decision-making, which is surrounded by a range of factors that influence the choices at each of the five cores stages. The influencing factors, all supported by empirical research, include individual student features, e.g. social background and academic ability (Li and Bray 2007); environmental factors, e.g. economic conditions and media influences (Mazzarol and Soutar 2002); characteristics of high schools and higher education institutions (Chapman 1981); factors specific to developed countries, which include individual attitudes and values, such as the need and desire for personal freedom and individual achievement (Mazzarol and Soutar 2002), and environmental differences, such as the increased role of marketing and the shift in influence from the family to the media, as well as the influences of globalisation and changes in the macro-environment (King, Findlay, and Ahrens 2010). The model leads the authors to reflect on institutional strategies to deal with the increasing complexity of student choice. They argue the need for branding and improved marketing communications, the need for greater personal attention and improved customer care, and the need to pay greater attention to business ethics and social responsibility.

The model proposed by Cubillo, Sánchez, and Cerviño (2006) focuses much more on institution, city and country images than the model developed by Vrontis et al. (2007). Cubillo et al.'s (2006) model shows the purchase decision as a variable dependent on five factors: personal reasons, evaluation of programme of study, country image, city image and institution image. Prospective students consider these five elements both consciously and unconsciously in order to arrive at a final choice.

Given that higher education can be life changing, and requires considerable commitment in terms of time (usually 3 or 4 years for a bachelor's degree), it is important that prospective students acquire adequate information to make a well-informed decision (Briggs 2006; Simões and Soares 2010), although making these choices may not always be based on adequate information, but maybe more on perceptions and interpretations (Baldwin and James 2000). This seems to suggest that the information searching stage of the student decision-making process requires students to be wellorganised and to devote considerable time and effort to the task in order to achieve the data that is needed or desired. Students typically conduct an internal search, retrieving existing information 
Wilkins, S. and Huisman, J. (2014). Factors affecting university image formation among prospective higher education students: the case of international branch campuses. Studies in Higher Education, published online before print, $8^{\text {th }}$ April 2014. http://dx.doi.org/10.1080/03075079.2014.881347.

from their memories, such as knowledge from past experiences, and an external search, which involves gathering new information (Blackwell, Miniard, and Engel 2006). Parents, teachers and higher education advisers generally encourage students to plan and conduct a systematic information search against a set of pre-determined criteria, which might take into account the student's ability and career ambitions, and the level of tuition fees that the student, or their families, can afford. However, across all types of products, consumers tend to search for more information when purchasing services, because services are seen as involving more risks.

The external information search can involve students gathering information from both personal and non-personal sources. Using a classification proposed by Olshavsky and Wymer (1995), external information sources can be grouped as those involving inspection by the student (e.g. open days and taster days), those controlled by the university (e.g. institution web sites and prospectuses/viewbooks), those provided by independent sources (e.g. media rankings and government quality reports), those provided by parties with an interest in the student's choice (e.g. higher education agents, which are used by many international students) and interpersonal sources (e.g. alumni, friends, family and teachers).

Studies undertaken by Simões and Soares (2010) in Portugal and by Sojkin, Bartkowiak, and Skuza (2012) in Poland found that the information sources used most often by prospective students are the Internet (university web sites and forums), brochures and literature produced by universities and the recommendations of friends and current or former students of universities. Student behaviour is however often ill-informed, and students might consider image as an important component of perceived quality (Baldwin and James 2000). With skilful branding and marketing, institutions can often project an image of high quality when actual quality is in fact considerably lower (Naidoo 2007).

The greater a student perceives their decision as involving high risks, the more likely he/she is to want to engage in direct observation and inspection, and to use interpersonal sources, which allow elucidation and feedback (Simões and Soares 2010). Vrontis et al. (2007) propose that academic ability, gender and personality are determinants of students' decision-making behaviour, and Menon (2004) found that students of lower socio-economic status are more likely to engage in active information searching, possibly because compared to higher status students they perceive higher education as involving greater financial risk.

Previous research has found a connection between preferred information sources and individual factors. For example, Chen (2008) found that preferences for relying on different marketing and interpersonal sources varied significantly between graduate and undergraduate students, while Wilkins and Huisman (2011a) found different preferences among students of different nationality. In countries such as Malaysia, Singapore and the UAE, expatriates account for large proportions of total enrolments at branch campuses. Living away from their home countries, expatriate children lose regular contact with extended families, old friends and other key support people from their communities and come to rely much more on their parents and siblings to meet their emotional and social needs (McLachlan 2007). A study of expatriate children in the UAE found that parents played an influential role in their children's higher education decision making process, with parents providing advice and guidance, facilitating the acquisition of information - for example, by buying books on higher education or by taking their children to higher education exhibitions - and directly expressing their views and preferences (Wilkins 2013).

This section has provided an overview of various models and approaches to explaining students' decision-making. Virtually all models of student choice involve, at least in some form, an information seeking stage. Prospective students typically undertake both internal and external searches and, as they gain information, they might construct multiple images of a single institution before making a decision on whether to reject, consider further or submit an application to it. Regardless of the sources of information and influence impacting on a student's decision-making, there is consensus in the literature (both the conceptual literature and empirical studies) that perceived organisational images are a key determinant of students' choices. Given the context of our research (expatriate 
Wilkins, S. and Huisman, J. (2014). Factors affecting university image formation among prospective higher education students: the case of international branch campuses. Studies in Higher Education, published online before print, $8^{\text {th }}$ April 2014. http://dx.doi.org/10.1080/03075079.2014.881347.

students in the UAE), it is likely that interpersonal sources and cultural factors are also influential in the student decision making process.

\section{Method}

The data for this research came from a survey of year 12/13 high school students (corresponding to grades $11 / 12$ in the US and Indian education systems) at international schools in the UAE. The UAE is an appropriate country in which to conduct this research since it hosts more international branch campuses than any other country (37 at the start of 2012, according to Lawton and Katsomitros 2012). To measure the key concepts in our study, like the antecedents of image construction, existing scales in the literature could not be used without considerable modification since none relate specifically to the overseas subsidiaries of multi-national organisations and we wanted scales that were appropriate for international branch campuses. Hence, an exploratory approach to the research was deemed appropriate.

To aid item development for the self-completed questionnaire and to ensure content validity and reliability, a pilot study was conducted. Twenty-three students were interviewed at four international schools in the UAE during one week in January 2012. Each semi-structured interview lasted about 20-30 minutes and was audio recorded. The interviewees also completed a draft questionnaire, which was designed by the authors, based on a thorough search and analysis of the student choice and decision-making literature. We specifically used Pampaloni (2010) and Williams and Moffitt (1997) for items on university features and university controlled communications, and Arpan, Raney, and Zivnuska (2003) and Kazoleas, Kim, and Moffitt (2001) for items on interpersonal relationships and non-university controlled communications. More generally, we made use of Wilkins and Huisman's (2011a, 2011b) work that investigated questions similar to ours.

The interviewees provided some useful feedback for improving several questions that could have been more clearly phrased or which could be made more suitable for the UAE context. However, the pilot study did not generate any new items. However, whereas the final survey yielded quantitative data, the pilot study yielded some rich qualitative data that enabled a degree of triangulation to occur, to corroborate findings and conclusions. Where there was some disagreement in the findings of the pilot study and the final survey, e.g. in the importance of home campus prestige and heritage, this has been identified in the discussion section.

The final questionnaire, distributed as hard copies that required handwritten responses, had 41 questions. Eight questions collected basic background data about the students, such as gender, nationality, parent's occupation (main income earner in family) and subject to be studied at university. The remaining questions involved students stating the extent to which they thought the listed factors influenced their overall impressions of particular branch campuses. Students' overall impressions or perceptions of a particular institution represent our operationalization of image construction. Examples of items are: information on university web sites; information gained at university open days; location of campus in UAE; historic campus in home country; feedback from current/past students; and recommendations of careers/higher education adviser. These questions were answered using 7-point Likert-type rating scales, where $1=$ not at all, and $7=$ to an extremely large extent.

Some of the students in the population will remain in the UAE for their higher education while others will go to universities outside the UAE. We are interested in identifying the sources of information used by these students and other sources of influence that impact upon the images they form of international branch campuses in the UAE. A convenience approach was used to find schools that were willing to participate in the study. Five international schools agreed to distribute our questionnaire to their students during an eight-week period, which started in the second half of March 2012 and ended in the first half of May 2012. None of the schools had participated in the pilot study, so there was no possibility of an individual respondent completing the questionnaire twice. 
Wilkins, S. and Huisman, J. (2014). Factors affecting university image formation among prospective higher education students: the case of international branch campuses. Studies in Higher Education, published online before print, $8^{\text {th }}$ April 2014. http://dx.doi.org/10.1080/03075079.2014.881347.

The schools received 796 questionnaires for distribution (including two schools that printed the questionnaires themselves). Most questionnaires were filled in during class. 466 completed questionnaires were returned and 384 were deemed usable, resulting in a usable response rate of $48.2 \%$. Respondents apparently did not struggle with the content of the questions as such, for the response rates by item hardly differed and we did not observe any survey fatigue (i.e. fewer or less reliable responses to items towards the end of the questionnaire). Most of the unusable questionnaires either had whole sections with no answers or the respondent had clearly not completed the questionnaire conscientiously or with reasonable care; for example, a questionnaire having the same value for all responses. Having critically discarded potentially misinterpreted questionnaires and wilfully misguiding responses, we think the responses used do yield a reliable and valid picture. Because we left the administration of the questionnaires to the schools, we were assured of a good level of response and a reasonable trust in the reliability of the responses, but one of the few downsides is that we could not perform a non-response analysis. The generalisability of the findings may be limited, given our focus on the UAE, but we argue (see also the next section) that the findings are at least largely representative for the UAE.

\section{Results}

The nationalities of the respondents were broadly representative of the expatriate population in the UAE: 53.9\% were South Asian (mainly Indian and Pakistani); 14.3\% European; 13.8\% Middle Eastern; 7.3\% African; 5.2\% North American (US and Canada); and 5.5\% 'other'. The sample comprised of 46.9\% males and $53.1 \%$ females; $51.0 \%$ were in their penultimate year of secondary education, 49.0\% were in their final year; $39.8 \%$ were following the CBSE Indian curriculum, 32.0\% were taking the International Baccalaureate, $11.8 \%$ were following a UK curriculum (mainly A-levels), and $16.4 \%$ were following a US curriculum; $18.0 \%$ had already applied to at least one higher education institution, meaning $82.0 \%$ had not yet submitted any higher education applications. Of the 70 students that had already applied to specific universities, $25.7 \%$ intended to stay in the UAE, while $74.3 \%$ hoped to gain places at universities outside the UAE. The most popular destination countries for those planning to leave the UAE were the UK (34.3\% of the 70 students), India (15.7\%), the US (11.4\%) and Canada (7.0\%).

The most popular disciplines for higher education study were professional subjects (such as accounting, business, information technology and media studies) and science/engineering subjects (particularly medicine and various types of engineering). Some $49.2 \%$ of the respondents intended to study a professional subject, while $33.6 \%$ planned to pursue a programme in the science/engineering field; $3.4 \%$ planned to study in the arts and humanities, $5.7 \%$ in the social sciences, and $8.1 \%$ were undecided. Our sample is broadly representative of the subjects studied in UAE higher education. For example, in Dubai in 2012, $47 \%$ of the students in higher education were studying business or information technology while only $8 \%$ were studying subjects in the humanities (KHDA 2013).

Globally, international branch campuses have tended to specialise in professional subjects because these are relatively cheap to establish, they can accommodate high student numbers, they are popular with students, who believe they will secure good jobs upon graduation, and also with host country governments that see these subjects as contributing to economic development and increased participation in labour markets (McBurnie and Ziguras 2007). Hence, our sample is typical of those found in higher education hubs such as Malaysia, Qatar, Singapore and the UAE.

The National Readership Survey (NRS) classification was used to categorise respondents according to socio-economic group membership. The NRS demographic classification system has six levels: grade $A$ at the top, representing professionals and senior managerial staff (upper middle class); grade B for intermediate managers and senior administrative staff (middle class); grade C1 for supervisory, administrative and junior management positions (lower middle class); grade C2 for skilled manual workers (skilled working class); grade D for semi-skilled and unskilled manual workers 
Wilkins, S. and Huisman, J. (2014). Factors affecting university image formation among prospective higher education students: the case of international branch campuses. Studies in Higher Education, published online before print, $8^{\text {th }}$ April 2014. http://dx.doi.org/10.1080/03075079.2014.881347.

(working class); and grade $\mathrm{E}$ for those living at the lowest levels of subsistence. No respondents in the study were classified as grade $\mathrm{E}$.

Given the relatively high cost of tuition fees at international schools in the UAE (even though they are often paid by employers for workers that have been recruited from abroad), it is not surprising that $74.7 \%$ of respondents classified themselves as belonging to socio-economic groups A, B or C1, and only $6.2 \%$ classified themselves as C2 or D. Some $19.0 \%$ of respondents classified their parent's (main income earner in family) occupation as 'other'. From the pilot study it was found that many students found it difficult to classify their parent's occupation, for example, when their parents owned their own business or held positions such as engineer or consultant. Examples such as these should really be added to the A, B or C1 categories, so the $74.7 \%$ quoted above is probably an underestimation.

Exploratory factor analysis using principal components with Varimax rotation was conducted (using SPSS version 19) to determine the underlying components of 33 potential sources of information and influence on the images formed by students of international branch campuses in the UAE. The Kaiser-Meyer-Olkin test produced a value of .88, far higher than the cut-off point of .70 , thus indicating that the sample size of 384 was adequate. The Bartlett test of sphericity $(p=$ .000 ) indicates that the data has a high enough degree of correlation between at least a number of variables, making it suitable for exploratory factor analysis. Using the criteria eigenvalue $>0.70$ (deemed acceptable by Jolliffe 1986) and factor loading $>.50$, six factors were extracted, which accounted for $72.6 \%$ of total variance (Table 1 ).

Table 1. Factor loadings for sources of information and influence on the images of international branch campuses formed by potential students

\begin{tabular}{|c|c|c|c|c|c|c|}
\hline & INT & UCC & LCF & LBF & CNC & HHP \\
\hline \multicolumn{7}{|l|}{ INTERPERSONAL } \\
\hline Recommendations of parents/relatives & .874 & & & & & \\
\hline Recommendations of teachers & 814 & & & & & \\
\hline Feedback from current/past students & .758 & & & & & \\
\hline \multicolumn{7}{|l|}{ UNIVERSITY CONTROLLED COMMUNICATIONS } \\
\hline University prospectuses/viewbooks and literature & & .790 & & & & \\
\hline University web sites & & .774 & & & & \\
\hline University open days & & .693 & & & & \\
\hline \multicolumn{7}{|l|}{ LOCAL CAMPUS FEATURES } \\
\hline Attractiveness of UAE campus & & & .814 & & & \\
\hline Location of UAE campus & & & .755 & & & \\
\hline Sports and leisure facilities at UAE campus & & & 701 & & & \\
\hline \multicolumn{7}{|l|}{ LOCAL BRANCH FEATURES } \\
\hline Level of tuition fees at UAE branch & & & & .783 & & \\
\hline Entry requirements at UAE branch & & & & .773 & & \\
\hline Range of courses offered at UAE branch & & & & .677 & & \\
\hline \multicolumn{7}{|l|}{ COMMUNICATIONS NOT CONTROLLED BY UNIVERSITY } \\
\hline Government inspection reports & & & & & .782 & \\
\hline Social media and internet blogs & & & & & .751 & \\
\hline \multicolumn{7}{|l|}{ HOME CAMPUS HERITAGE AND PRESTIGE } \\
\hline Historic campus in home country & & & & & & .830 \\
\hline Home campus has educated Nobel Prize winners & & & & & & .743 \\
\hline Eigenvalue & 5.82 & 1.32 & 1.25 & 1.13 & 0.98 & 0.89 \\
\hline Variance (\%) & 36.38 & 8.23 & 7.80 & 7.09 & 6.13 & 5.57 \\
\hline Cumulative variance (\%) & 36.38 & 44.61 & 52.41 & 59.50 & 65.63 & 71.20 \\
\hline Cronbach's alpha & .86 & .74 & .74 & .74 & .65 & .70 \\
\hline
\end{tabular}


Wilkins, S. and Huisman, J. (2014). Factors affecting university image formation among prospective higher education students: the case of international branch campuses. Studies in Higher Education, published online before print, $8^{\text {th }}$ April 2014. http://dx.doi.org/10.1080/03075079.2014.881347.

The six factors are named Interpersonal (INT), University controlled communications (UCC), Local campus features (LCF), Local branch features (LBF), Communications not controlled by university (CNC) and Home campus heritage and prestige (HHP). Internal reliability of the factors was tested using Cronbach's alpha. The alpha values ranged from .65 to .86 , indicating adequate consistency within each factor. Although Nunnally (1978) stipulated .70 as the minimum value to indicate adequate reliability, Janssens et al. (2008) claim that values above .60 can be considered a 'good' result, particularly in exploratory research. Furthermore, Cronbach's alpha is very sensitive to the number of items in a factor and thus works best when there are a minimum of three items (Janssens et al. 2008). In the case of factors with only two items, such as our CNC and HHP factors, alpha values above .60 can be acceptable (lacobucci and Duhachek 2003).

Our findings indicate that the factor that has the greatest influence on the images of international branch campuses formed by potential students is 'Interpersonal', i.e. recommendations and feedback resulting from personal relationships, which explains $36.4 \%$ of total variance. University controlled communications (university prospectuses/viewbooks and literature; university web sites; and university open days) are the second greatest influence, explaining $8.2 \%$ of variance. Interestingly, the image formed of a branch campus in the UAE is affected not only by a range of factors related to the local branch (e.g. features of the campus, level of tuition fees and entry requirements), which explained $14.9 \%$ of total variance (LCF + LBF), but also by aspects of the home campus image and performance (e.g. whether the institution is old and has a historic campus, and whether it has educated Nobel Prize winners), which explained $5.6 \%$ of total variance (HHP). Performance indicators such as educating Nobel Prize winners might be used by potential students as indicators of prestige and education quality. Institutional rankings (based on home campuses, since international branch campuses are rarely included in league tables) appeared to have considerable influence on the images of international branch campuses formed by students, but the rankings variable was omitted from the final component matrix because it correlated strongly with items in different factors.

To investigate whether the impacts of different sources of information and influence on university image formation differ between males and females, students of different nationality and socio-economic background, and students intending to study different types of subjects, one-way between-groups multivariate analysis of variance (MANOVA) was performed. The assumptions associated with conducting MANOVA were confirmed, e.g. Box's test (.45) indicated homogeneity of covariance matrices and non-significant Levene's tests indicated homogeneity of error variances. On the combined dependent variables comprising the six components, there appears a statistically significant difference between males and females $[F(6,377)=4.89, p=.000$, Wilks' $\lambda=.928]$. The remaining tests yielded non-significant results (Appendix 1 ).

Univariate analysis of variance was performed as post-hoc analysis. It was found that statistically significant differences between males and females existed for the following factors: 'Interpersonal' at the .001 level of significance, and 'University controlled communications' and 'Local branch features' at the .05 level. For each of the factors, females awarded higher scores than males, except for 'Local campus features' (Males: mean $=4.53, S D=1.30$; Females: mean $=4.32, \mathrm{SD}=1.24$ ). Further analysis revealed a significant difference at the .05 level between students intending to study different types of subjects and 'Local campus features'.

\section{Discussion}

Numerous studies have investigated the influences on students' higher education choices. The most common influences can often be placed into one of three categories: institution features/characteristics, informational resources and interpersonal sources. Our findings indicate that the factor 'Interpersonal', reflecting recommendations and feedback resulting from personal relationships has by far ( $36.4 \%$ of variance explained) the greatest influence on the images of international branch campuses formed by potential students. These findings are echoed by the 
Wilkins, S. and Huisman, J. (2014). Factors affecting university image formation among prospective higher education students: the case of international branch campuses. Studies in Higher Education, published online before print, $8^{\text {th }}$ April 2014. http://dx.doi.org/10.1080/03075079.2014.881347.

findings from the interviews in the pilot study, in which students explained their reliance on interpersonal sources, particularly on parents and relatives, as a social norm in their (South Asian and Middle Eastern) cultures.

Our study contradicts some studies that found that interpersonal sources were of limited influence (e.g. Chen 2008; Maringe 2006; Moogan, Baron, and Harris 1999; Pampaloni 2010; Soutar and Turner 2002), but supports other research, which has found personal recommendations very influential, particularly from parents and relatives (e.g. Gatfield and Chen 2006; Kazoleas, Kim, and Moffitt 2001; Mazzarol and Soutar 2002; Padlee, Kamaruddin, and Baharun 2010; Shanka, Quintal, and Taylor 2005; Simões and Soares 2010; Sojkin, Bartkowiak, and Skuza 2012; Wilkins and Epps 2011; Wilkins and Huisman 2011a).

Bonnema and Van der Waldt (2008) suggested that preferred information sources varied among different subgroups of students that had different interests/motivations or different socio-economic backgrounds. Mazzarol and Soutar (2002) found that the influence of personal recommendations varied substantially across students in different countries; for example, $80 \%$ of Indonesian students indicated that recommendations from parents and relatives were an important influencing factor in their choice of host country, compared to only $52 \%$ of Chinese students. The distinctive and different family expectations and upbringing of boys and girls among certain ethnic and religious groups commonly found in the UAE seems to explain the significant cultural differences found between males and females in our study. We found differences by nationality, subject and socio-economic background as well, but these were not significant, which may be explained by the dominance of the sample by students from South Asia.

Part of the explanation for the importance of interpersonal sources goes back to cultural factors. In addition, the fact that reliable and independent data on international branch campuses are lacking, explains the reliance on interpersonal sources. Although the quality assurance agencies in the UAE have for some time made publicly available details of school inspections and audits undertaken, comparable information for international branch campuses has not been put into the public domain. However, organisations such as the Commission for Academic Accreditation (CAA), the Knowledge and Human Development Authority (KHDA) and the University Quality Assurance International Board (UQAIB) have recently begun to make more information publicly available

The explanation building on cultural factors needs elaboration, which can be done by considering the socio-economic dimension, since $97.9 \%$ of the respondents in our sample came from expatriate families. Expatriate families are typically smaller family units consisting of only parents and children, and as a result expatriate families are often stronger and more cohesive (McLachlan 2007). This is another fact that explains why in our survey even children from countries in Europe and North America were influenced heavily by recommendations from their parents. Also, the fact that these children do not usually have extended family living nearby might explain why recommendations from teachers were more influential than has been found in other studies (e.g. Chen 2007; Wilkins and Huisman 2011a). A further elaboration is that the influential factors do not relate solely to the family context. Feedback from current and past students is another item in the 'Interpersonal' component. Feedback from current students and alumni allow elucidation and might enable students to feel that they are minimising the risks associated with choosing a higher education institution.

While our research confirms and elaborates upon previous research on student choice, a rather novel finding pertains to the images of home versus branch campus. It was found in the pilot study that for elite institutions, the reputation and prestige of the home campus could have a strong influence on the images formed of the branch campus. This seemed to benefit well-known institutions such as New York University, as students judged the academic quality of its international branch campus in Abu Dhabi by the reputation and rankings achieved by the institution's home campus in New York. However, across all institutions, home campus images were found to have only a moderate influence on the images constructed of branch campuses, which implies that only the most elite institutions can benefit from superior home campus heritage and prestige. 
Wilkins, S. and Huisman, J. (2014). Factors affecting university image formation among prospective higher education students: the case of international branch campuses. Studies in Higher Education, published online before print, $8^{\text {th }}$ April 2014. http://dx.doi.org/10.1080/03075079.2014.881347.

Despite the respondents of the pilot study emphasising the importance of home campus reputation and prestige, the mean score given by students for 'home campus heritage and prestige' in the main survey was somewhat lower than that given for all of the other influencing factors (Appendix 1). It is possible that in the pilot study the nature of the detailed questioning and the fact that respondents were expected to offer an explanation or justification for their opinions may have encouraged the students to consider more carefully the determinants of the images they held of different specific institutions.

\section{Implications for higher education institutions}

The findings suggest that institutions must achieve student satisfaction and encourage, even reward, positive word of mouth. Dissatisfied students might engage in negative word of mouth, which could be extremely damaging to an institution's reputation. Achieving positive word of mouth from current students and alumni is a vital element in every institution's promotional mix. In many cultures - including those commonly found in the Middle East - people often have a strong preference for engaging in oral communication over written communication. Even when students resort to written sources of information, they are more likely to respond to information they found on their own, for example using social media and internet blogs, rather than to advertising and marketing communications sent to them by institutions (Pampaloni 2010). In order to achieve positive word of mouth, institutions need to first achieve student satisfaction. Student satisfaction is not determined solely by the students' teaching and learning experiences but rather by their overall experiences as a customer of a particular institution. Therefore, institutions must carefully manage every aspect of the student's interactions with its service offerings, because the quality of each service encounter experienced by students - or each 'moment of truth' - will form part of their overall impression of the whole service provided (Carlzon 1989).

Due to the increased competition for international students among home and branch campuses, institutions should seriously consider to develop and maintain a positive and distinctive image in order to achieve a competitive advantage. Branding has become a popular tool used by institutions to communicate their desired images. Blythe $(2006$, p. 89$)$ defines branding as 'the culmination of a range of activities across the whole marketing mix, leading to a brand image which conveys a whole set of messages to the consumer'. Hence, in the context of higher education, brand image might be regarded as a component of a university's overall image.

Progressive institutions often employ specialist branding and corporate identity managers, who typically concentrate their efforts on strengthening the university's image with regard to prestige and/or quality (Sung and Yang 2008). Universities can use corporate branding to communicate institutional strengths and values in a way that differentiates them from competitors and which promotes esteem and admiration from stakeholders, which can result in the development of a positive reputation. A university's image is what stakeholders perceive it to be at a particular moment in time whereas reputation is not based on immediate representations but rather on the deeper sets of enduring images held by stakeholders over time (Maringe and Gibbs 2009, p. 136).

Although our findings suggest that students' images of international branch campuses are influenced mainly by the views and recommendations of 'significant others', those significant others might themselves be influenced by branding and reputation. Furthermore, branding activities can have an influence on local campus features, local branch features and home campus heritage and prestige (other factors in our model), which suggests that branding and reputation are as important to students assessing international branch campuses as students assessing universities in any other country or context (see also Vrontis, Thrassou, and Melanthiou, 2007).

Achieving positive word of mouth and developing a strong corporate brand seems a straightforward solution to image challenges, but these are just two elements of the marketing mix (and more broadly all facets of the student experience, from initial contacts with a higher education institution to leaving the institution as a graduate and alumnus) that need to be managed. In other words, image-building and branding should not be seen as the sole recipe to influence student 
Wilkins, S. and Huisman, J. (2014). Factors affecting university image formation among prospective higher education students: the case of international branch campuses. Studies in Higher Education, published online before print, $8^{\text {th }}$ April 2014. http://dx.doi.org/10.1080/03075079.2014.881347.

decision-making. We explore this by stressing three pitfalls that come along with too much stress on branding and identity management. First, corporate and marketing communications are also important. As students can be influenced by multiple 'significant others', institutions must communicate regularly and effectively with each of these stakeholders, which include parents, schools, employers, regulatory bodies and the media; what is suggested is a comprehensive and integrated communications strategy.

A further complication to branding and imaging is that it is difficult to conceptualize a university in one single image because each department, each college, each collection of professors possess their own images. Also, each stakeholder may hold different and multiple images simultaneously because each stakeholder uses different criteria when assessing an institution (Arpan, Raney, and Zivnuska 2003). As higher education has become increasingly commodified, possibly universities have had to act more like business organisations, but it is important that they actively pursue ways to address social and community needs in order to maintain a positive image among all stakeholders (Kazoleas, Kim, and Moffitt 2001).

Furthermore, universities cannot be excellent at everything and they cannot address the needs of every customer group, so they should identify specific aspects around which they can position themselves (Maringe and Gibbs 2009). Positioning involves specifying and communicating the desired organisational image so that the students in the target segment understand what the university stands for in relation to other institutions in the market. Establishing a distinctive image seems to be key because students generally judge universities on their reputations and not on the actual quality of their teaching or research (Marginson 2006).

The finding that potential customers might form images of international branch campuses based on information and perceptions related to both branch and home campuses highlights the complex nature of the organisational image formation process. It places a demanding task on identity managers to create and maintain positive organisational images. This brings us to a final comment on taking into account status differences in the hierarchy of universities. Lower status institutions with branch campuses will have to be ever more innovative and creative in their marketing communications and activities to create and maintain a favourable image that enables them to compete on other than a low cost-low quality proposition. But even high status and prestigious institutions should be aware that disasters or scandals at their home campuses could damage their reputations and have a negative knock-on effect on the images formed of their international branch campuses; so, contingency planning is recommended to deal with such circumstances.

\section{Conclusion}

Given that students are often not rational decision makers (Baldwin and James 2000), it appears that many students rely on perceived institutional images rather than 'hard facts' to assess individual institutions. At any one time, a student may hold multiple images of an institution - for example, of different departments, and regarding things such as campus location, academic quality and social life - and these images are likely to change over time as the student gains new information or has new experiences or thoughts. This research has identified some of the critical factors that influence image formation.

This is one of the first studies that has focused on the sources of information and influence that impact upon the images of international branch campuses formed by potential students. Explaining $36.4 \%$ of total variance, it was found that interpersonal sources of information and influence had the greatest impact upon the university images constructed by prospective students. In the UAE, and also most likely in the other higher education hubs hosting large numbers of expatriate students, prospective students rely heavily on information shared by parents, teachers and current/past students. Arguably, this information may be factual, but it has obviously qualities distinctive from information from universities' own communications, and factual information related to campus features, tuition fees, and entry requirements. Cultural factors, especially relating to characteristics of the expatriate family, appear to dominate the decision-making process and hence the image 
Wilkins, S. and Huisman, J. (2014). Factors affecting university image formation among prospective higher education students: the case of international branch campuses. Studies in Higher Education, published online before print, $8^{\text {th }}$ April 2014. http://dx.doi.org/10.1080/03075079.2014.881347.

formation process of the students in our sample. The importance of interpersonal sources of information and influence on student choices highlights to institutions the need to carefully manage their reputations and communications with all stakeholders, particularly those who directly influence students, such as parents and teachers.

Potential higher education students typically undertake their decision-making in stages; first considering a broader range of institutions and then narrowing them down to a shortlist. At some point, the individual will draw upon their research, beliefs, ideas, feelings and impressions about a particular institution. Our findings suggest that how we ask students about the images they hold of different institutions might determine the quality of data achieved because respondents involved in semi-structured face-to-face interviews might be encouraged to offer more detailed and plausible responses. That said, the findings of the main survey were not dissimilar to a lot of the existing literature on student choice.

This research is not without limitations given that it relied on a relatively small sample obtained using the convenience sampling strategy in a single country. The findings may not therefore be generalizable to all potential international students currently residing in or close to a higher education hub that hosts international branch campuses. That said, there are many similarities between the higher education hubs in terms of branch campus characteristics and local demographic features, as well as the main disciplines offered by international branch campuses (Knight 2011; McBurnie and Ziguras 2007). Further research might confirm the generalizability of our findings.

\section{References}

Abubakar, B., T. Shanka, and G.N. Muuka. 2010. Tertiary education: An investigation of location selection criteria and preferences by international students - The case of two Australian universities. Journal of Marketing for Higher Education 20, no. 1: 49-68.

Arpan, L.M., A.A. Raney, and S. Zivnuska. 2003. A cognitive approach to understanding university image. Corporate Communications: An International Journal 8, no. 2: 97-113.

Baldwin, G., and R. James. 2000. The market in Australian higher education and the concept of student as informed consumer. Journal of Higher Education Policy and Management 22, no. 2: 139-48.

Ball, S.J., J. Davies, M. David, and D. Reay. 2002. 'Classification' and 'judgement': Social class and the 'cognitive structures' of choice of higher education. British Journal of Sociology of Education 23, no. 1: 51-72.

Benneworth, P., and B.W. Jongbloed. 2010. Who matters to universities? A stakeholder perspective on humanities, arts and social sciences valorisation. Higher Education 59, no. 5: 567-88.

Blackwell, R.D., P.W. Miniard, and J.F. Engel. 2006. Consumer behavior. $10^{\text {th }}$ edition. Mason, OH: Thomson/South-Western.

Blythe, J. 2006. Essentials of marketing management. $3^{\text {rd }}$ edition. London: Prentice Hall.

Bodycott, P. 2009. Choosing a higher education study abroad destination. Journal of Research in International Education 8, no. 3: 349-73.

Bonnema, J., and D.L.R Van der Waldt. 2008. Information and source preferences of a student market in higher education. International Journal of Education Management 22, no. 4: 314-27.

Briggs, S. 2006. An exploratory study of the factors influencing undergraduate student choice: The case of higher education in Scotland. Studies in Higher Education 31, no. 6: 705-22.

Brown, T.J., P.A. Dacin, M.G. Pratt, and D.A. Whetten. 2006. Identity, intended image, construed image, and reputation: An interdisciplinary framework and suggested terminology. Journal of the Academy of Marketing Science 34, no. 2: 99-106.

Carlzon, J. 1989. Moments of truth. New York: HarperCollins.

Chapman, D. W. 1981. A model of student college choice. The Journal of Higher Education 52, no. 5: 490-505. 
Wilkins, S. and Huisman, J. (2014). Factors affecting university image formation among prospective higher education students: the case of international branch campuses. Studies in Higher Education, published online before print, $8^{\text {th }}$ April 2014. http://dx.doi.org/10.1080/03075079.2014.881347.

Chen, L.H. 2007. Choosing Canadian graduate schools from afar: East Asian students' perspectives. Higher Education 54, no. 5: 759-80.

Chen, L.H. 2008. International marketing? Two frameworks for understanding international students' choice of Canadian universities. Journal of Marketing for Higher Education 18, no. 1: 133.

Cubillo, J., J. Sánchez, and J. Cerviño. 2006. International students' decision-making process. International Journal of Educational Management 20, no. 2: 101-15.

Dunnett, A., J. Moorhouse, C. Walsh, and C. Barry. 2012. Choosing a university: A conjoint analysis of the impact of higher fees on students applying for university in 2012. Tertiary Education and Management 18, no. 3: 199-220.

Eccles, J.S., and A. Wigfield. 2002. Motivational beliefs, values, and goals. Annual Review of Psychology 53, no. 1: 109-32.

Gatfield, T., and C. Chen. 2006. Measuring student choice criteria using the theory of planned behaviour: The case of Taiwan, Australia, UK, and USA. Journal of Marketing for Higher Education 16, no. 1: 77-95.

Holmegaard, H.T., L.M. Ulriksen, and L.M. Madsen. 2012. The process of choosing what to study: A longitudinal study of upper secondary students' identity work when choosing higher education. Scandinavian Journal of Educational Research, published online 21 June 2012. DOI: 10.1080/00313831.2012.696212.

Hossler, D., J. Schmit, and N. Vesper. 1999. Going to college. How social, economic, and educational factors influence the decisions students make. Baltimore, MD: John Hopkins University Press.

lacobucci, D., and A. Duhachek. 2003. Advancing alpha: Measuring reliability with confidence. Journal of Consumer Psychology 13, no. 4: 478-87.

Janssens, W., K. Wijnen, P. De Pelsmacker, and P. Van Kenhove. 2008. Marketing research with SPSS. Harlow: Pearson Education.

Jolliffe, I.T. 1986. Principal component analysis. New York: Springer.

Karaosmanoglu, E., and T.C. Melewar. 2006. Corporate communications, identity and image: A research agenda. Journal of Brand Management 14, nos. 1/2: 196-206.

Kazoleas, D., Y. Kim, and M.A. Moffitt. 2001. Institutional image: A case study. Corporate Communications: An International Journal 6, no. 4: 205-16.

KHDA. 2013. The higher education landscape in Dubai 2012. Dubai: Knowledge and Human Development Authority.

King, R., A. Findlay, J. Ahrens, and M. Dunne. Reproducing advantage: The perspective of English school leavers on studying abroad. Globalisation, Societies and Education 9, no. 2: 161-81.

Knight, J. 2011. Education hubs: A fad, a brand, an innovation? Journal of Studies in International Education 15, no. 3: 221-40.

Lawton, W., and A. Katsomitros. 2012. International branch campuses: Data and developments. London: The Observatory on Borderless Higher Education.

Li, M., and M. Bray. 2007. Cross-border flows of students for higher education: Push-pull factors and motivations of mainland Chinese students in Hong Kong and Macau. Higher Education 53, no. 6: 791-818.

Mangan, J., A. Hughes, and K. Slack. 2010. Student finance, information and decision making. Higher Education 60, no. 5: 459-72.

Marginson, S. 2006. Dynamics of national and global competition in higher education. Higher Education 52, no. 1: 1-39.

Maringe, F. 2006. University and course choice: Implications for positioning, recruitment and marketing. International Journal of Educational Management 20, no. 6: 466-79.

Maringe, F., and S. Carter. 2007. International students' motivations for studying in UK HE: Insights into the choice and decision making of African students. International Journal of Educational Management 21, no. 6: 459-75. 
Wilkins, S. and Huisman, J. (2014). Factors affecting university image formation among prospective higher education students: the case of international branch campuses. Studies in Higher Education, published online before print, $8^{\text {th }}$ April 2014. http://dx.doi.org/10.1080/03075079.2014.881347.

Maringe, F., and P. Gibbs. 2009. Marketing higher education: Theory and practice. Maidenhead: Open University Press/McGraw Hill.

Mazzarol, T., and G.N. Soutar. 2002. 'Push-pull' factors influencing international student destination choice. International Journal of Educational Management 16, no. 2: 82-90.

McBurnie, G., and C. Ziguras. 2007. Transnational education: Issues and trends in offshore higher education. Abingdon: Routledge.

McCulloch, A. 2009. The student as co-producer: Learning from public administration about the student-university relationship. Studies in Higher Education 34, no. 2: 171-83.

McLachlan, D.A. 2007. Global nomads in an international school: Families in transition. Journal of Research in International Education 6, no. 2: 233-49.

Menon, M.E. 2004. Information search as an indication of rationality in student choice of higher education. Education Economics 12, no. 3: 267-83.

Moogan, Y., S. Baron, and K. Harris. 1999. Decision-making behaviour of potential higher education students. Higher Education Quarterly 53, no. 3: 211-28.

Mikkonen, J., A. Heikkilä, M. Ruohoniemi, and S. Lindblom-Ylänne. 2009. "I study because I'm interested": University students' explanations for their disciplinary choices. Scandinavian Journal of Educational Research 53, no. 3: 229-44.

Naidoo, R. 2007. Higher education as a global commodity: The perils and promises for developing countries. London: The Observatory on Borderless Higher Education.

Nunnally, J.C. 1978. Psychometric theory. $2^{\text {nd }}$ edition. New York: McGraw-Hill.

OECD. 2011. Higher education at a glance. Paris: OECD.

Olshavsky, R.W., and W. Whymer. 1995. The desire for new information from external sources. In Proceedings of the Society for Consumer Psychology, ed. S. Mackenzie and R. Stayman, 17-27, Bloomington, IN: Printmaster.

Padlee, S.F., A.R. Kamaruddin, and R. Baharun. 2010. International students' choice behaviour for higher education at Malaysian private universities. International Journal of Marketing Studies, 2, no. 2: 202-11.

Pampaloni, A.M. 2010. The influence of organizational image on college selection: What students seek in institutions of higher education? Journal of Marketing for Higher Education 20, no. 1: 1948.

Shanka, T., V. Quintal, and R. Taylor. 2005. Factors influencing international students' choice of an education destination - A correspondence analysis. Journal of Marketing for Higher Education 15, no. 2: 31-46.

Simões, C., and A.M. Soares. 2010. Applying to higher education: Information sources and choice factors. Studies in Higher Education 35, no. 4: 371-89.

Smyth, E., and J. Banks. 2012. "There was never really any question of anything else": Young people's agency, institutional habitus and the transition to higher education. British Journal of Sociology of Education 33, no. 2: 263-81.

Sojkin, B., P. Bartkowiak, and A. Skuza. 2012. Determinants of higher education choices and student satisfaction: The case of Poland. Higher Education 63, no. 5: 565-81.

Soutar, G.N., and J.P. Turner. 2002. Students' preferences for university: A conjoint analysis. International Journal of Educational Management 16, no. 1: 40-5.

Spittal, R.D., and R. Abratt. 2009. The impact of geographic expansion on intended identity of an organisation. Journal of General Management 35, no. 1: 65-78.

Sung, M. and S.U. Yang. 2008. Toward the model of university image: The influence of brand personality, external prestige, and reputation. Journal of Public Relations Research 20, no. 4: 35776.

Tight, M. 2013. Students: Consumers, clients, pawns? Higher Education Policy 26, no. 3: 291-307.

Vrontis, D., A. Thrassou, and Y. Melanthiou. 2007. A contemporary higher education student-choice model for developed countries. Journal of Business Research 60, no. 9: 979-89. 
Wilkins, S. and Huisman, J. (2014). Factors affecting university image formation among prospective higher education students: the case of international branch campuses. Studies in Higher Education, published online before print, $8^{\text {th }}$ April 2014. http://dx.doi.org/10.1080/03075079.2014.881347.

Wilkins, S. 2013. 'Home' or away? The higher education choices of expatriate children in the United Arab Emirates. Journal of Research in International Education 12, no. 1: 33-48.

Wilkins, S., M.S. Balakrishnan, and J. Huisman. 2011. Student choice in higher education: Motivations for choosing to study at an international branch campus. Journal of Studies in International Education 16, no. 5: 413-33.

Wilkins, S., and A. Epps. 2011. Student evaluation web sites as potential sources of consumer information in the United Arab Emirates. International Journal of Educational Management 25, no. 5: 410-22.

Wilkins, S., and J. Huisman. 2011a. Student recruitment at international branch campuses: Can they compete in the global market? Journal of Studies in International Education 15, no. 3: 299-316.

Wilkins, S., and J. Huisman. 2011b. International student destination choice: The influence of home campus experience on the decision to consider branch campuses. Journal of Marketing for Higher Education 21, no. 1: 61-83.

Williams, S. L., and M. A. Moffitt. 1997. Corporate image as an impression formation process: Prioritising personal, organizational, and environmental audience factors. Journal of Public Relations Research 9, no. 4: 237-58.

Appendix 1. MANOVA test results

\begin{tabular}{|c|c|c|c|c|c|c|}
\hline Components & & Group & means & (SD) & & $F$ \\
\hline GENDER & Male & Female & & & & \\
\hline Interpersonal & $4.27(1.48)$ & $4.77(1.39)$ & & & & $4.89 * * *$ \\
\hline Uni control comm & $4.67(1.14)$ & $4.93(1.23)$ & & & & \\
\hline Local campus feat & $4.53(1.30)$ & $4.32(1.24)$ & & & & \\
\hline Local branch feat & $4.54(1.38)$ & $4.89(1.41)$ & & & & \\
\hline Non-uni control comm & $4.12(1.46)$ & $4.28(1.42)$ & & & & \\
\hline Home campus prestige & $3.43(1.49)$ & $3.55(1.51)$ & & & & \\
\hline NATIONALITY & African & European & Mid East & Nth Am & Sth Asia & \\
\hline Interpersonal & $4.46(1.41)$ & $4.19(1.45)$ & 4.69 (1.49) & $4.75(1.50)$ & $4.58(1.43)$ & 1.22 \\
\hline Uni control comm & $4.40(1.37)$ & $4.87(1.16)$ & $4.84(1.26)$ & $4.63(0.75)$ & $4.84(1.21)$ & \\
\hline Local campus feat & $4.57(1.32)$ & $4.25(1.40)$ & $4.74(1.40)$ & $4.48(1.47)$ & $4.34(1.20)$ & \\
\hline Local branch feat & $4.37(1.47)$ & $4.51(1.50)$ & $4.67(1.34)$ & 4.65 (1.44) & $4.87(1.34)$ & \\
\hline Non-uni control comm & $3.95(1.52)$ & $4.18(1.32)$ & $4.31(1.55)$ & $3.80(1.26)$ & $4.27(1.44)$ & \\
\hline Home campus prestige & $3.14(1.52)$ & $3.21(1.52)$ & $3.49(1.60)$ & $3.35(1.05)$ & $3.58(1.52)$ & \\
\hline SOCIO-ECONOMIC & A & B & $\mathrm{C} 1$ & $\mathrm{C} 2$ & D & \\
\hline Interpersonal & $4.59(1.38)$ & $4.52(1.54)$ & $4.43(1.36)$ & $4.67(1.44)$ & $3.83(0.23)$ & 0.89 \\
\hline Uni control comm & $4.94(1.23)$ & $4.79(1.24)$ & $4.86(0.79)$ & $4.52(1.32)$ & $5.00(0.94)$ & \\
\hline Local campus feat & $4.44(1.23)$ & 4.54 (1.33) & $4.42(0.91)$ & $4.24(1.50)$ & $4.50(0.24)$ & \\
\hline Local branch feat & $4.76(1.53)$ & $4.56(1.32)$ & 4.76 (1.19) & $5.06(1.22)$ & $4.67(0.47)$ & \\
\hline Non-uni control comm & $4.28(1.42)$ & $4.16(1.47)$ & $4.13(1.27)$ & $4.05(1.78)$ & $4.75(1.06)$ & \\
\hline Home campus prestige & $3.59(1.60)$ & $3.26(1.46)$ & 3.60 (1.37) & $3.84(1.53)$ & $3.50(0.71)$ & \\
\hline SUBJECT & Humanities & Sci \& Eng & Soc Sci & Prof & Undecided & \\
\hline Interpersonal & $4.72(1.64)$ & $4.37(1.44)$ & $4.32(1.35)$ & $4.64(1.45)$ & $4.58(1.52)$ & 1.05 \\
\hline Uni control comm & $4.82(1.30)$ & $4.69(1.22)$ & $4.76(0.92)$ & 4.95 (1.17) & $4.45(1.30)$ & \\
\hline Local campus feat & $4.56(1.49)$ & $4.24(1.21)$ & $3.94(1.30)$ & $4.60(1.24)$ & $4.29(1.47)$ & \\
\hline Local branch feat & $4.92(1.25)$ & 4.59 (1.39) & $4.76(1.63)$ & 4.84 (1.39) & $4.47(1.41)$ & \\
\hline Non-uni control comm & $4.15(1.72)$ & $4.17(1.42)$ & $3.86(1.55)$ & 4.31 (1.47) & $4.02(1.05)$ & \\
\hline Home campus prestige & $2.81(1.25)$ & $3.58(1.58)$ & $3.23(1.51)$ & $3.55(1.45)$ & $3.29(1.56)$ & \\
\hline
\end{tabular}

Note: ${ }^{* * *}$ Significant at $p<.001$ 